\title{
The biological prospective of red-pigmented bacteria cultured from contaminated agar media
}

\author{
ACHMAD ARIFIYANTO`, HAPIN AFRIANI, MEISHY HANDERLIN PUTRI, BERLIANA DAMAYANTI, \\ CINDY LUKYTA RATIH RIYANTO
}

Department of Biology, Faculty of Mathematics and Natural Sciences, Universitas Lampung. Jl. Prof. Soemantri Brojonegoro No 1, Bandar Lampung 35144, Lampung, Indonesia. Tel.: +62-721-704625, Fax.: +62-721-704625, `email: achmad.arifiyanto@ fmipa.unila.ac.id

Manuscript received: 7 November 2020. Revision accepted: 4 February 2021

\begin{abstract}
Arifiyanto A, Afriani H, Putri MH, Damayanti B, Riyanto CL. 2021. The biological prospective of red-pigmented bacteria cultured from contaminated agar media. Biodiversitas 22: 1152-1159. Contaminated agar media was often depleted due to the growth of microbes, which is undesirable for culture. However, the contaminating microbes usually have a distinctive morphology. This research aimed to identify the potential of red-pigmented bacteria originated from the contamination of Drosophila melanogaster larvae. Fruit fly larvae that grow on contaminated tryptic soy agar were accompanied by the appearance of the red-pigmented bacteria colony. The bacterial colonies were purified by the re-streaking method on tryptic soybean agar. This strain was characterized morphologically, biochemically, and molecularly. Results showed that the MBC1 strain was identified as Serratia marcescens. The various metal susceptibility tests at $25 \mathrm{ppm}$ did not affect the growth of the MBC1 strain. Meanwhile, it was also able to inhibit the growth of certain pathogens such as Aspergillus niger, Candida sp., Fusarium sp., and Rigidoporous sp. Strain MBC1 was able to produce antioxidant compounds. The lipolytic and amylolytic activity can be developed for bioremediate agriculture waste and biosurfactant production.
\end{abstract}

Keywords: Contaminated culture, Drosophila melanogaster, red-pigmented bacteria, prospect, Serratia

\section{INTRODUCTION}

Microbial contamination was an unexpected problem in cell culture. Re-production of fermentation must be pursued if the culture media was contaminated. Longer time and additional media became inefficiency constraints due to contamination. The presence of non-target microbe growth was one of the causes of contamination. Repeated use of glassware was may also increase the likelihood of contamination. The source of contamination frequently also arose from media culture. The airborne particulates from the environment also increased the chances of contamination (Mirjalili et al. 2005).

The nutritional content in the contaminated media often attracts insects. Insects have been known as a microbial vector. Genera Staphylococcus and Weissella were dominantly found at microbial communities of the house fly Musca domestica (Park et al. 2019). Acetobacter thailandicus identified as bacteria that were mutually associated with Drosophila melanogaster (Pais et al. 2018). D. melanogaster was also reported as a host of certain genera of yeast like Candida, Cryptococcus, Hanseniaspora, Hanusula, Kloeckera, Kluyveromyces, Pichia, Rhodotorula, Saccharomyces, Saccharomycopsis, and Torulopsis (Broderick and Lemaitre 2012). Lactic acid bacteria Enterococci played a role in modulating Drosophila to lay eggs on decaying food. Females were lay eggs at rotting material, trash, fruits, and human food. These microorganisms were developed and attract other females to perch and lay eggs (Liu et al. 2017).
In the present investigation, we study the contaminated culture on which D. melanogaster larvae were grown. Increasing the number of growing larvae was able to inhibit the growth of fungi, which grow in the contaminated media. From several piles of Petri overgrown with larvae, the pigmented bacterial colony showed a zone of inhibition against nearby molds. Thus, we proposed to investigate the biological prospect of red-pigmented bacteria cultured from contaminated agar media.

\section{MATERIALS AND METHODS}

\section{Bacteria culture}

All contaminated culture media in Petri dishes were closed without sealing so that wild $D$. melanogaster larvae developed on them. The colony of red-pigmented microbes that inhibited fungal growth isolated and purified into ISP1, ISP2, Nutrient agar, Potato Dextrose Agar (PDA), Trypticase soy agar, or tryptone soya agar (TSA) media (HiMedia $\left.{ }^{\circledR}\right)$. Microbial growth was observed and characterized according to Suryawanshi et al. (2014).

The isolate was identified by morphological, physiological, biochemical (Abdullah et al. 2017), and molecular approaches. Molecular identification of isolate was tested using primers 27F5'AGAGTTTGATCCTGGCTCAG-3' and 1492R5'GGTTACCTTGTTACGACTT3' (Macrogen). PCR (25 $\mu \mathrm{L}$ final volume) was carried out by mixing $2.5 \mu \mathrm{L} 10 \mathrm{X}$ PCR buffer, $0.5 \mu \mathrm{L}$ mixtures of dNTP, $1.0 \mu \mathrm{L}$ of each PCR 
primer, $0.5 \mu \mathrm{L}$ of Taq DNA polymerase, and $1.0 \mu \mathrm{L}$ of each template DNA. Initial denaturation was carried out for 25 seconds at a temperature of $94{ }^{\circ} \mathrm{C}$. Then it was reconstructed at $94{ }^{\circ} \mathrm{C}$ for 10 seconds for 35 cycles. Annealing was taken at $46{ }^{\circ} \mathrm{C}$ for 30 seconds. The elongation was continued at $72{ }^{\circ} \mathrm{C}$ for 1.5 minutes. Meanwhile, the last extension occurred at $72{ }^{\circ} \mathrm{C}$ for 10 minutes. The PCR results were further sequenced and the results compared with other bacterial sequences in Genbank

\section{Susceptibility test}

A susceptibility test toward antibiotic was conducted using the disk diffusion method. The antibiotics used consisted of nystatin, chloramphenicol, clindamycin, ampicillin, streptomycin, griseofulvin, fluconazole. The dose tested was 10 and $20 \mu \mathrm{g} / \mathrm{L}$ (Bengtsson-Palme and Larsson 2016).

\section{Hemolytic test}

The hemolysis ability of the isolates was tested using the blood agar method. It was incubated for 1-2 days at room temperature. The activity of the tested bacteria was observed according to hemolysis type (Arifiyanto et al. 2020).

\section{Hydrolase enzyme test}

The hydrolase enzymes consisting of lipase, chitinase, mannanase, cellulase, amylase, protease, were tested on the test isolate. Test conducted in qualitative method and measured for enzyme index to compare. Isolate Streptomyces AB8 was used as a control (Agustina et al. 2019; Arifiyanto et al. 2020; Garcia-Orozco et al. 2019; Rosa et al. 2020; Sumardi et al. 2020).

\section{Fermentation media}

The fermentation media was optimized by culturing isolate into certain fermentation media (TSA, TSA+yeast, Nutrient broth, Mueller Hilton Broth, ISP4, ISP9, Trypton water, Tauge extract media, Sucrose solution, rice washing water, yeast-starch broth, and gelatine). Culture with good color formation was selected (Chambers et al. 2019; Priyatno et al. 2011; Trudgeon et al. 2020). The starter was made by adding $1 \mathrm{~mL}$ of isolate (cell turbidity adjusted to 0.5 McFarland standard) into $9 \mathrm{~mL}$ of fermentation medium at room temperature $(180 \mathrm{rpm})$ and incubating for 3 days. The 3-day old starter was put into $990 \mathrm{~mL}$ of fermentation medium and incubated for 6 days. Growth curves were made by taking $1 \mathrm{~mL}$ of culture and measured at a wavelength of $600 \mathrm{~nm}$ twice a day. The cultures were harvested and centrifuged at $3000 \mathrm{rpm}$ for 30 minutes. The filtrate obtained was an extracellular pigment and pellets were extracted using methanol to obtain intracellular pigments. The filtrate was extracted with $70 \%$ methanol (1: 1) added and left for 12 hours to obtain pure pigment (Asnani et al. 2016). In this study, the extracellular pigment was obtained.

\section{Antioxidant test}

Antioxidant activity was measured using the DPPH method (Castro et al. 2019) The materials used were DPPH (2.2 diphenyl-1-picrylhidrazyl) (Sigma). $4 \mathrm{mg}$ of DPPH was dissolved in $25 \mathrm{~mL}$ of methanol in a volumetric flask as a stock solution (equivalent to a concentration of $160 \mathrm{mg}$ / L). The resulting solution was stored in a dark room and protected with aluminum foil. Stock solutions were diluted with concentrations of 20,40,60,80, and $100 \mathrm{mg} / \mathrm{L}$. The absorbance was measured using a spectrophotometer at 515 $\mathrm{nm}$. A total of $20 \mu \mathrm{L}$ of samples were mixed with $180 \mu \mathrm{L}$ of DPPH (concentration of $150 \mu \mathrm{M}$ ) in dark conditions and allowed to stand for 30 minutes then measured the absorbance at $\lambda 515 \mathrm{~nm}$. The blank solution used consisted of $20 \mu \mathrm{L}$ methanol in $180 \mu \mathrm{L}$ DPPH measured at the same wavelength (Ab). Trolox was used as a positive control. The DPPH test treatment was carried out in three repetitions (triplicate). During the reduction process by antioxidants, the DPPH radical solution changed color from purple to pale yellow. Sample measurement can be seen in equation 1 .

$$
\% \text { inhibition }=\left[1-\frac{A k-A s}{A k}\right] \cdot 100
$$

Where:

As: absorbance sample

Ak: absorbance control

\section{Antimicrobial activity test}

The pathogen Aspergillus niger, Candida sp., Escherichia coli, Fusarium sp., Rigidoporous sp. Dickeya sp. var 5., Dickeya sp. var 10., Trichoderma sp., were prepared as much as $100 \mu \mathrm{L}$ with a concentration of $10^{8}$ CFU/ mL to be grown on Mueller Hinton Agar (MHA) media. The inhibition test was carried out using the paper disc method. $10 \mu \mathrm{L}$ extract was dropped on $6 \mathrm{~mm}$ filter paper. The same treatment was carried out on methanol which was used as a control. The cultures were incubated for 24 hours at room temperature and the diameter of the inhibition zone was measured (Arifiyanto et al. 2020).

\section{RESULTS AND DISCUSSION}

\section{Identification}

Based on the identification result (Tabel 1) strain MBC1 had certain characters. The cells were rod-shaped, motile, and Gram-negative bacteria. It showed an oxidase negative and catalase-positive test.

Culturing in various media was conducted to figure out appropriate media for fermentation. MBC1 were produced red pigment in TSA, MHA, tryptone water, gelatine, tauge extract media (TEM). The result of Gram staining was suggested that the MBC1 isolate belongs to the genus Serratia, molecular identification using 16S rRNA obtained a similar result (Figure 1). 
Table 1. Morphology and biochemical characters of isolate $\mathrm{MBC} 1$

\begin{tabular}{|c|c|}
\hline Test & Result \\
\hline Gram/ KOH & $-/+$ \\
\hline Indole & + \\
\hline Aerobic fermentation & + \\
\hline Lipase & + \\
\hline Oxidase & - \\
\hline Cellulases & + \\
\hline Protease & + \\
\hline Arginine & + \\
\hline Casein & + \\
\hline Amylase & + \\
\hline Chitinase & + \\
\hline Mannanase & + \\
\hline Catalase & + \\
\hline Motility & + \\
\hline \multicolumn{2}{|l|}{ Antibiotics } \\
\hline Nystatin & - \\
\hline Chloramphenicol & - \\
\hline Clindamycin & - \\
\hline Ampicillin & - \\
\hline Streptomycin & - \\
\hline Griseofulvin & - \\
\hline Fluconazole & - \\
\hline \multicolumn{2}{|l|}{ Metals } \\
\hline $\mathrm{MgSO}_{4}$ & + \\
\hline $\mathrm{AgNO}_{3}$ & + \\
\hline $\mathrm{CuSO}_{4}$ & + \\
\hline $\mathrm{BaCl}_{2}$ & + \\
\hline $\mathrm{HgCl}_{2}$ & + \\
\hline $\mathrm{FeSO}_{4}$ & + \\
\hline $\mathrm{PbNO}_{3}$ & + \\
\hline \multicolumn{2}{|l|}{ C sources } \\
\hline Fructose & + \\
\hline Galactose & + \\
\hline Glucose & + \\
\hline Glycerol & + \\
\hline Lactose & + \\
\hline Maltose & + \\
\hline Mannitol & + \\
\hline Starch & + \\
\hline Sucrose & + \\
\hline Cellulose & + \\
\hline \multicolumn{2}{|l|}{ Media } \\
\hline TSA & Red \\
\hline TSA + yeast & No color \\
\hline NA & No color \\
\hline MHA & Red \\
\hline ISP 4 & No color \\
\hline ISP 9 & No color \\
\hline Tryptone Water & Red \\
\hline Gelatine & Red \\
\hline TEM & Red \\
\hline Sucrose solution & No color \\
\hline Rice washing water & No color \\
\hline YSB & No color \\
\hline Blood agar & $\gamma$ \\
\hline NA+ urea & Red \\
\hline
\end{tabular}

Bacterial cell growth was observed for 10 days density measurements carried out in the morning and evening (Figure 2). The data in Figure 2 performed that the growth pattern of the MBC1 strain of bacteria tends to be stable at no more than 0.3 OD at the measured cell density using a spectrophotometer. On the other hand, the AB8 strain bacteria showed a peak increase on day $7^{\text {th }}$ reached 0.8 OD. These data indicate that the period required for the two strains of bacteria for optimum growth was different. The MBC1 strain bacteria grew optimally on the 3rd day while AB8 required a week to grow. This data used in the fermentation process to obtain pigment metabolite.

\section{The potency of cells activity}

\section{Hydrolase enzyme}

Based on the screening of the enzyme activity index (Figure 3), the MBC 1 strain was found superior to $\mathrm{AB} 8$ (Streptomyces control) in the enzyme activity of lipase and amylase. On the other hand, AB8 strains showed only slightly superior results in chitinase, cellulase, and protease enzymes.

The results were compared with the antioxidant assay by the influence of heavy metals. Trolox as control was detected to reach a lower peak than metal treatment. Heavy metals have been shown to increase the absorbance and antioxidant ability of the pigment Serratia marcescens strain $\mathrm{MBC1}$ (figure 4). On the other hand, a greater heavy metal dose was given as it reduced the antioxidants activity.

\section{Antimicrobial activity}

In addition to the antioxidant activity, efforts were also made to identify the antimicrobial potential of the MBC1 and $\mathrm{AB} 8$ strains. The results of antimicrobial activity are presented in figure 6 . Bacteria strain $\mathrm{AB} 8$ was able to inhibit the growth of Dickeya sp. var 5 and var10 and Aspergillus niger only. On the other hand, the MBC1 strain was able to inhibit several pathogens, namely Aspergillus niger, Candida sp., Fusarium sp. and Rigidoporous sp.

\section{Discussion}

Pigments or dyes are commonly encountered in higher organisms such as animals, plants, and even molds. However, it was not uncommon also to be found in microorganisms such as bacteria. The pigmented bacteria groups include Agrobacterium aurantiacum (Pink-red), Staphylococcus aureus (golden yellow), Chromobacterium violaceum (purple), Serratia marcescens (red), Bacillus spp. (creamy white), Flavobacterium sp (yellow). Even pigments were keys to identifying species (Abdulkadir 2017). Pigments are used in industry to make a wide variety of colors, some of which are water-soluble. Pigments produced by many microorganisms are non-toxic, so that they are environmentally friendly and can be used as dyes, foodstuffs, pharmaceuticals, cosmetics, and other industrial needs. Bacterial pigments show antioxidant, and antimicrobial activity (Arifiyanto et al. 2020), They can also be used as additives, color enhancers, and anticancer (Azman et al. 2018). Micrococcus roseus and Rhodotorula glutinis were produced red pigments beside the member of genera Serratia sp (Rostami et al. 2016). 
Phylogenetic tree result indicated that the MBC1 strain was closely related to Serratia ureilytica. Serratia ureilytica was a sub-species of Serratia marcescens that used urea as a source of nitrogen for its growth (Bhadra et al. 2005). Serratia was Gram-negative bacteria, a member of the $\gamma$-Proteobacteria subclass and grouped by the Enterobacteriaceae family (Bhadra et al. 2005). Several genera of the genus, namely species belonging to this genus. Serratia marcescens, Serratia liquefaciens, Serratia plymuthica, Serratia rubidaea, Serratia fonticola, Serratia marnorubra, Serratia proteamaculans, and Serratia odorifera were reported as pathogens by (Horinouchi et al. 2010). Serratia has a wide range of habitats. They had frequently been isolated from soil, water, and animals (García-Fraile et al. 2015). They are also often found in association with plants and insects. Serratia marcescens AL2-16 that associated with Achyranthes aspera L was reported to enhance plant growth-promoting properties (Devi et al. 2016). Serratia ureilytica species were found from extreme environmental habitats (Filippidou et al. 2019). Drosophila melanogaster had known to be a source of microbial association host, Serratia was included (Chambers et al. 2019; Gilbert et al. 2020). Prodigiosin was a red pigment which was the characteristic of this genus (Azman et al. 2018).

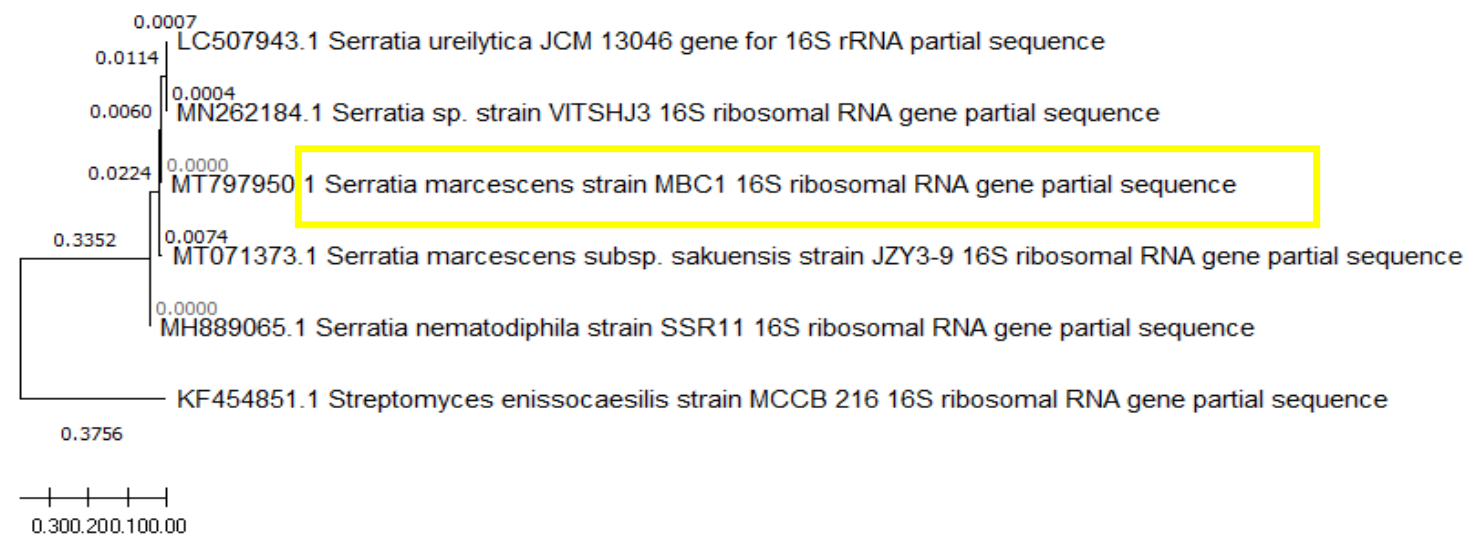

Figure 1. Phylogenetic tree of the Serratia marcescens MBC1 strain with the access code MT797950

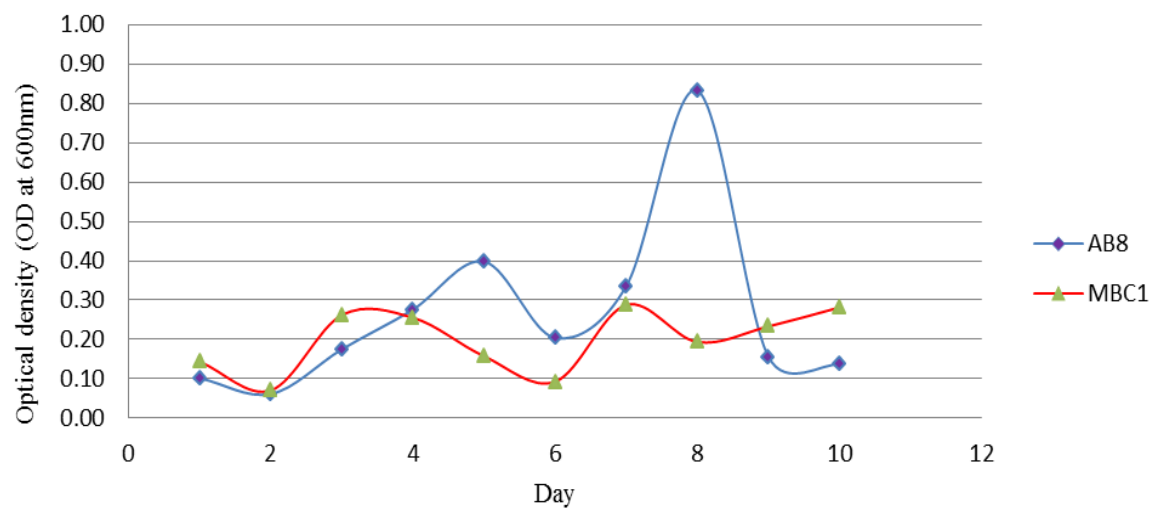

Figure 2. The growth curves of AB8 and MBC1 


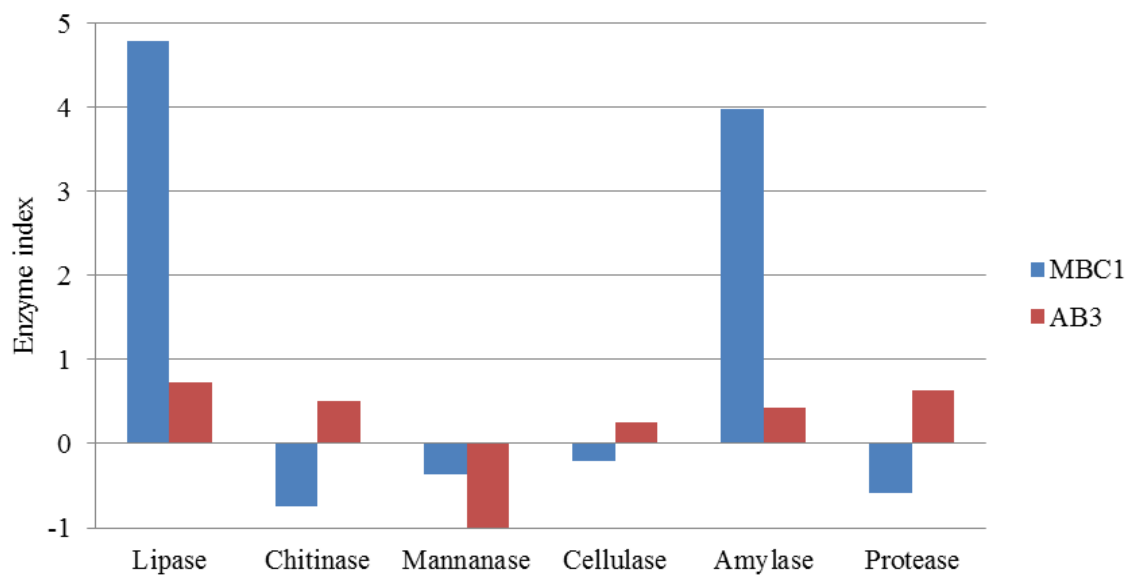

Figure 3. The enzyme index of the bacteria strains $\mathrm{AB} 8$ and $\mathrm{MBC} 1$

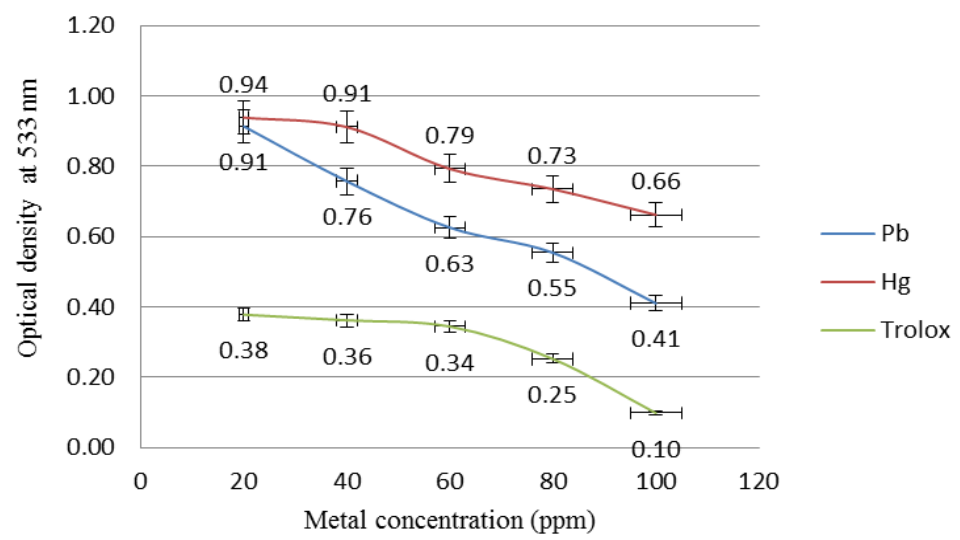

Figure 4. The effect of lead and mercury on the cell density of the pigment of Serratia marcescens strain MBC1. Linear equation for Pb $(y=-0.219 x+3.98)$ and $\mathrm{Hg}(\mathrm{y}=-0.3626 x+3.0435)$ to determine lethal concentration (LC50).

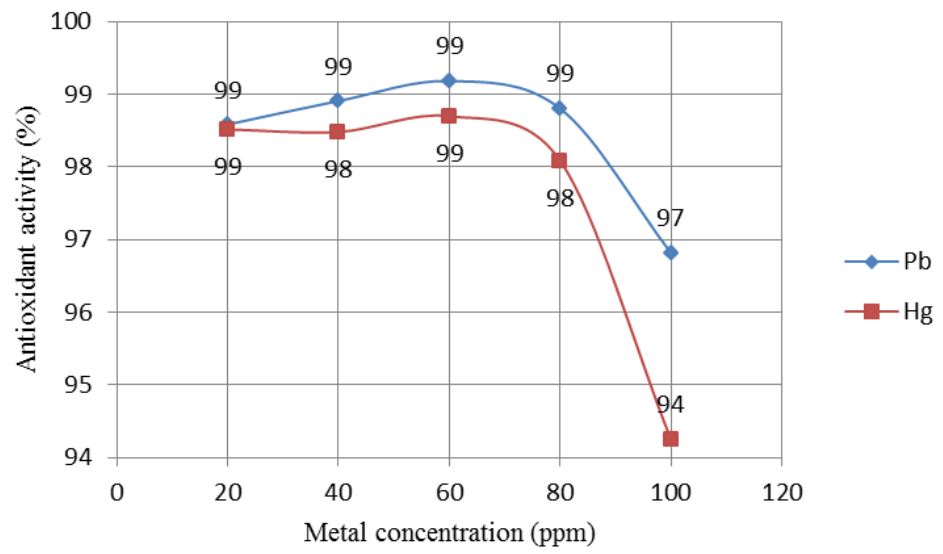

Figure 5. The antioxidant activity of the pigment Serratia sp on lead and Mercury. 


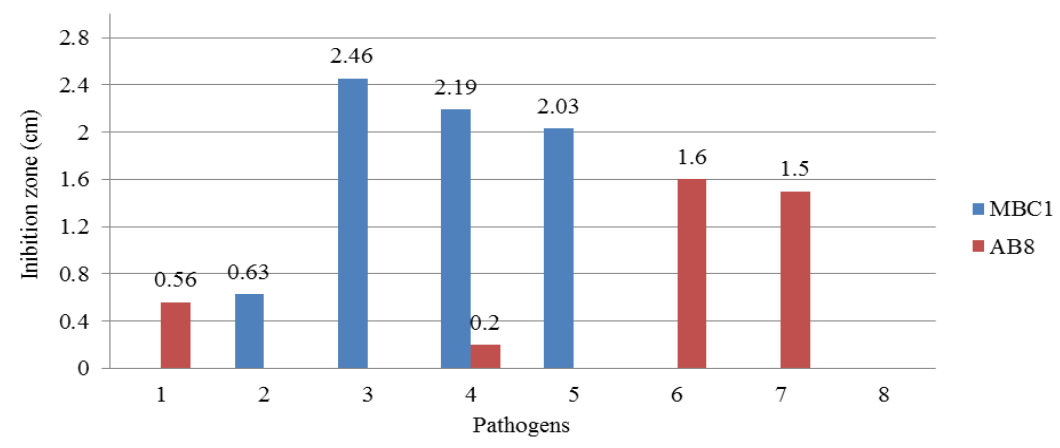

Figure 6. Antimicrobial activity of the MBC1 and AB8 1) Escherichia coli, 2) Candida sp., 3) Fusarium sp., 4) Aspergillus niger, 5) Rigidoporous sp. 6) Dickeya sp. var 5, 7) Dickeya sp. var 10, and 8) Trichoderma sp.

Antioxidant activity was induced by the presence of heavy metals (Gjorgieva et al. 2013). The result showed that antioxidants were higher in the stress treatment of $\mathrm{Hg}$ than $\mathrm{Pb}$. The reason is that Mercury was more toxic rather than lead (Arifiyanto et al. 2017). According to Tristantini et al. (2016), a compound that has IC50 below 50, might be categorized as a strong antioxidant. The linear equation in Figure 5 shows that the LC 50 is less than 50 . Using at $10 \mathrm{mg} / \mathrm{L}$ concentration DPPH and ABTS were completely hunted by prodigiosin (Arivizhivendhan et al. 2018). The pigment was a higher number on $\mathrm{Hg}$ compared to $\mathrm{Pb}$. This means that bacteria need more antioxidants that come from pigments. Both Serratia marcescens strain MBC1 and Streptomyces AB8 showed a decrease antioxidant activity when metal concentration was higher than $60 \mathrm{ppm}$. Gjorgieva et al. (2013) explained that high metal levels treatment also caused DNA damage.

Serratia marcescens strain MBC1 has the potential to act as a biocontrol agent. In addition to being antioxidant, Arivizhivendhan et al. (2018) reported that the prodigiosin pigment was also able to inhibit the growth of pathogens including S. aureus, E. coli, B. cereus, C. botulinum, V. vulnificus, and $S$. enteritidis.

The result of the susceptibility test exhibited that, Serratia sp strain MBC1 was not resistant to nystatin, chloramphenicol, clindamycin, ampicillin, streptomycin, griseofulvin, and even fluconazole. Hemolysis results also showed the type of gamma (no hemolysis). The $\gamma$ Hemolysin group was related to certain subunit combinations of the protein. One of the proteins regarding $\gamma$-Hemolysin or $\gamma$-toxin was beneficial for microbes to form colonization, while there was no information about pathogenicity. Thus $\gamma$-Hemolysin was not related to pathogens (Oliveira et al. 2018).

Lipolytic activity was interesting because it showed a significant index. Extracellular-lipolytic activities arose as a strategy for bacteria to survive in extreme environments (Cherif et al. 2011). Previously it has been proved that lipase activity is one of the screening steps in biosurfactant activity (Arifiyanto et al. 2020). Biosurfactants were defined as compounds that have much more efficient and stable, better in toxicity, biocompatibility, and biodegradability than chemical surfactants. The compound also able to obtained from waste fermentation using cassava flour wastewater according to (Araújo et al. 2019). It was supporting our data. Besides lipolytic activity, Serratia marcescens strain MBC1 has shown good amylase enzyme performance. It was also found by (Purkayastha et al. 2018) that the genus Serratia capable of producing chitinase, mannanase, and cellulase. It should be suitable if utilized in agricultural and marine bioremediation applications.

Consumption of various types of foodstuffs and higher emission rates also contribute to high free radicals. Free radicals are also known as reactive oxygen species (ROS). Antioxidants act to provide a protective effect on human health from oxidative damage caused by ROS (Tan et al. 2018). ROS can be derived from hydroxyl groups, superoxides, and peroxyl radicals that attack macromolecules including membrane lipids, proteins, and DNA (Bray 2000) which then cause serious health complications such as cancer (Farinati et al. 2010; Notarte et al. 2019) diabetes mellitus (Maritim et al. 2003) and neurodegenerative (Sun and Chen 1998) and chronic inflammatory diseases (Federico et al. 2007).

The characterization results in the red color pigment of the MBC1 strain was Serratia sp. The lipolytic and amylolytic activity could be developed to recycle agriculture waste and biosurfactant production. Their pigment was to be developed as protection of oxidants. This strain also showed the ability to inhibit some pathogens, so it has been suggested as biocontrol for the pathogen of crops.

\section{ACKNOWLEDGEMENTS}

We would like to express our gratitude and high appreciation to all who helped and supported this research. This study was funded by the University of Lampung, Indonesia (1482/UN26.21/PN/2020). 


\section{REFERENCES}

Abdulkadir N. 2017. Bacterial Pigments and its Significance. MOJ Bioequivalence Bioavailab 4 (3): 285-288. DOI: 10.15406/mojbb.2017.04.00073.

Abdullah AH, Al-Ammiri H, Al-Ammiri HH. 2017. Isolation and Identification of Serratia marcescens from Bovine Mastitis infections in Iraq and their Susceptibility to Antibiotics. J Entomol Zool Stud 5 (2): $489-492$

Agustina D, Surtiningsih T, Manuhara YSW, Arifiyanto A, Malewa M. 2019. Study of Cellulase Activity Produced by Penicillium sp. Aspergillus niger and Trichoderma viride on Imperata cylindrica (L.) Beauv. Enrichment Media. IOP Conf Ser: Earth Environ Sci. DOI: 10.1088/1755-1315/253/1/012016.

Araújo HWC, Andrade RFS, Montero-Rodríguez D, Rubio-Ribeaux D, Alves Da Silva CA, Campos-Takaki GM. 2019. Sustainable biosurfactant produced by Serratia marcescens UCP 1549 and its suitability for agricultural and marine bioremediation applications. Microb Cell Factories 18 (1): 1-13. DOI: 10.1186/s12934-018-1046-0

Arifiyanto A, Apriyanti FD, Purwaningsih P, Kalqutny SH, Agustina D, Surtiningsih T, Shovitri M, Zulaika E. 2017. Lead $(\mathrm{Pb})$ bioaccumulation; Genera Bacillus isolate S1 and SS19 as a case study. AIP Conf Proc 1854 (1): 020003. DOI: 10.1063/1.4985394.

Arifiyanto A, Surtiningsih T, Ni'matuzahroh, Fatimah, Agustina D, Alami N. 2020. Antimicrobial activity of biosurfactants produced by actinomycetes isolated from rhizosphere of Sidoarjo mud region Biocatalysis Agric Biotechnol 24. DOI: 10.1016/j.bcab.2020.101513.

Arivizhivendhan KV, Mahesh M, Boopathy R, Swarnalatha S, Regina Mary R, Sekaran G. 2018. Antioxidant and antimicrobial activity of bioactive prodigiosin produces from Serratia marcescens using agricultural waste as a substrate. J Food Sci Technol 55 (7): 2661 2670. DOI: $10.1007 / \mathrm{s} 13197-018-3188-9$

Asnani A, Ryandini D, Suwandri. 2016. Screening of marine actinomycetes from Segara Anakan for natural pigment and hydrolytic activities. IOP Conf Ser: Mater Sci Eng 107 (1). DOI: 10.1088/1757-899X/107/1/012056.

Azman AS, Mawang CI, Abubakar S. 2018. Bacterial pigments: The bioactivities and as an alternative for therapeutic applications. Na Prod Commun 13 (12): 1747-1754. DOI: $10.1177 / 1934578 \times 1801301240$.

Bengtsson-Palme J, Larsson DGJ. 2016. Concentrations of antibiotics predicted to select for resistant bacteria: Proposed limits for environmental regulation. Environ Intl 86: 140-149. DOI 10.1016/j.envint.2015.10.015.

Bhadra B, Roy P, Chakraborty R. 2005. Serratia ureilytica sp. nov., a novel urea-utilizing species. Int J Syst Evol Microbiol 55 (5): 21552158. 10.1099/ijs.0.63674-0.

Bray TM. 2000. Dietary antioxidants and assessment of oxidative stress Nutr J 16 (7-8): 578-581.

Broderick NA, Lemaitre B. 2012. Gut-associated microbes of Drosophila melanogaster. Gut Microb 3 (4). DOI: 10.4161/gmic.19896.

Castro LMG, Alexandre EMC, Pintado M, Saraiva JA. 2019. Bioactive compounds, pigments, antioxidant activity and antimicrobial activity of yellow prickly pear peels. Int J Food Sci Technol 54 (4):12251231. DOI: $10.1111 /$ ijfs. 14075 .

Chambers MC, Jacobson E, Khalil S, Lazzaro BP. 2019. Consequences of chronic bacterial infection in Drosophila melanogaster. PLoS ONE 14 (10): 1-22. DOI: 10.1371/journal.pone.0224440

Cherif S, Mnif S, Hadrich F, Abdelkafi S, Sayadi S. 2011. Strategy for improving extracellular lipolytic activities by a novel thermotolerant Staphylococcus sp. strain. Lipids Health Dis 10: 1-8. DOI: 10.1186/1476-511X-10-209.

Devi KA, Pandey P, Sharma GD. 2016. Plant Growth-Promoting Endophyte Serratia marcescens AL2-16 Enhances the Growth of Achyranthes aspera L., a Medicinal Plant. HAYATI J Biosci 23 (4): 173-180. DOI: 10.1016/j.hjb.2016.12.006.

Farinati F, Piciocchi M, Lavezzo E, Bortolami M, Cardin R. 2010. Oxidative stress and inducible nitric oxide synthase induction in carcinogenesis. Dig Dis 28 (4-5): 579-584.

Federico A, Morgillo F, Tuccillo C, Ciardiello F, Loguercio C. 2007. Chronic inflammation and oxidative stress in human carcinogenesis. Int J Cancer 121 (11): 2381-2386.

Filippidou S, Junier T, Wunderlin T, Kooli WM, Palmieri I, Al-Dourobi A, Molina V, Lienhard R, Spangenberg JE, Johnson SL, Chain PS 2019. Adaptive strategies in a poly-extreme environment:
Differentiation of Vegetative Cells in Serratia ureilytica and Resistance to Extreme Conditions. Front Microbiol 10 (FEB): 1-13. DOI: 10.3389/fmicb.2019.00102.

García-Fraile P, Chudíčková M, Benada O, Pikula J, Kolařík M. 2015. Serratia myotis $s p$. nov. and Serratia vespertilionis sp. nov., isolated from bats hibernating in caves. Int J Syst Evol Microbiol 65 (1): 9094. DOI: 10.1099/ijs.0.066407-0.

Garcia-Orozco KD, Cinco-Moroyoqui F, Angulo-Sanchez LT, MarquezRios E, Burgos-Hernandez A, Cardenas-Lopez JL, Gomez-Aguilar C, Corona-Martinez DO, Saab-Rincon G, Sotelo-Mundo RR. 2019. Biochemical characterization of a novel $\alpha / \beta$-hydrolase/FSH from the white shrimp Litopenaeus vannamei. Biomolecules 9 (11). DOI: 10.3390/biom9110674.

Gilbert R, Torres M, Clemens R, Hateley S, Hosamani R, Wade W, Bhattacharya S. 2020. Spaceflight and simulated microgravity conditions increase virulence of Serratia marcescens in the Drosophila melanogaster infection model. Npj Microgravity 6 (1): 19. DOI: $10.1038 / \mathrm{s} 41526-019-0091-2$

Gjorgieva D, Kadifkova Panovska T, Ruskovska T, Bačeva K, Stafilov T. 2013. Influence of heavy metal stress on antioxidant status and DNA damage in Urtica dioica. BioMed Res Int 2013. DOI: $10.1155 / 2013 / 276417$

Horinouchi S, Ueda K, Nakayama J, Ikeda T. 2010. 4.07 - Cell-to-Cell Communications among Microorganisms. Elsevier. DOI: 10.1016/B978-008045382-8.00098-8.

Liu W, Zhang K, Li Y, Su W, Hu K, Jin S. 2017. Enterococci mediate the oviposition preference of Drosophila melanogaster through sucrose catabolism. Sci Rep 7 (1): 1-14. DOI: 10.1038/s41598-017-13705-5.

Maritim A, Sanders RA, Watkins III JB. 2003. Diabetes, oxidative stress, and antioxidants. J Biochem Mol Toxicol 17 (1): 24-38.

Mirjalili A, Parmoor E, Moradi Bidhendi S, Sarkari B. 2005. Microbial contamination of cell cultures: A 2 years study. Biologicals 33 (2): 81-85. DOI: 10.1016/j.biologicals.2005.01.004.

Notarte KIR, Devanadera MKP, Mayor ABR, Cada MCA, Pecundo MH, Macabeo APG. 2019. Toxicity, antibacterial , and antioxidant activities of fungal endophytes Colletotrichum and Nigrospora spp. isolated from Uvaria grandiflora. Philippine J Sci 148 (September): 505-512.

Oliveira D, Borges A, Simões M. 2018. Staphylococcus aureus toxins and their molecular activity in infectious diseases. Toxins 10 (6). DOI: $10.3390 /$ toxins 10060252

Pais IS, Valente RS, Sporniak M, Teixeira L. 2018. Drosophila melanogaster establishes a species-specific mutualistic interaction with stable gut-colonizing bacteria. PLoS Biol 16 (7). DOI: 10.1371/journal.pbio.2005710.

Park R, Dzialo MC, Spaepen S, Nsabimana D, Gielens K, Devriese H, Crauwels S, Tito RY, Raes J, Lievens B, Verstrepen KJ. 2019. Microbial communities of the house fly Musca domestica vary with geographical location and habitat. Microbiome 7 (1): 1-12. DOI: 10.1186/s40168-019-0748-9.

Priyatno TP, Dahliani YA, Suryadi Y, Samudra IM, Susilowati DN, Rusmana I, Wibowo BS, Irwan C. 2011. Identifikasi entomopatogen bakteri merah pada wereng batang coklat (Nilaparvata lugens Stål.). Jurnal AgroBiogen 7 (2): 85. DOI: 10.21082/jbio.v7n2.2011.p85-95. [Indonesian]

Purkayastha GD, Mangar P, Saha A, Saha D. 2018. Evaluation of the biocontrol efficacy of a Serratia marcescens strain indigenous to tea rhizosphere for the management of root rot disease in tea. PLoS ONE 13 (2): 1-27. DOI: 10.1371/journal.pone.0191761.

Rosa E, Ekowati CN, Handayani T, Ikhsanudin A, Apriliani F, Arifiyanto A. 2020. Characterization of entomopathogenic fungi as a natural biological control of American cockroaches (Periplaneta americana). Biodiversitas 21(11). DOI: 10.13057/biodiv/d211131.

Rostami H, Hamedi H, Yolmeh M. 2016. Some biological activities of pigments extracted from Micrococcus roseus (PTCC 1411) and Rhodotorula glutinis (PTCC 5257). Int J Immunopathol Pharmacol 29 (4): 684-695. DOI: 10.1177/0394632016673846.

Sumardi, Farisi S, Ekowati CN, Arifiyanto A, Rahmawati DE. 2020. Halotolerant Bacillus sp. For mannan degradation isolated from mangrove ecosystem at Hanura beach Lampung. J Pure Appl Microbiol 14 (2): 1237-1244. DOI: 10.22207/JPAM.14.2.18.

Sun A, Chen Y. 1998. Oxidative stress and neurodegenerative disorders. J Biomed Sci 5 (6): 401-414.

Suryawanshi RK, Patil CD, Borase HP, Salunke BK, Patil SV. 2014. Studies on production and biological potential of prodigiosin by 
Serratia marcescens. Appl Biochem Biotechnol 173 (5): 1209-1221. DOI: 10.1007/s12010-014-0921-3.

Tan LTH, Chan KG, Chan CK, Khan TM, Lee LH, Goh B. H. 2018. Antioxidative potential of a Streptomyces sp. MUM292 isolated from mangrove soil. BioMed Res Int 2018. DOI: 10.1155/2018/4823126.

Tristantini D, Ismawati A, Pradana BT, Gabriel J. 2016. Pengujian aktivitas antioksidan menggunakan metode DPPH pada daun tanjung
(Mimusops elengi L ). In Seminar Nasional Teknik Kimia Kejuangan (p. 1). [Indonesian]

Trudgeon B, Dieser M, Balasubramanian N, Messmer M, Foreman CM. 2020. Low-Temperature Biosurfactants from Polar Microbes. Microorganisms 8 (8): 1183. DOI: 10.3390/microorganisms 8081183. 